J. Neurol. Neurosurg. Psychiat., 1955, 18, 199.

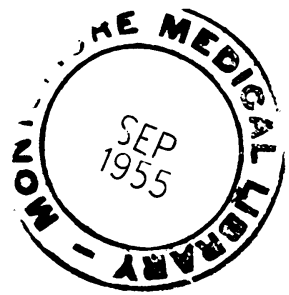

A BENIGN “TUMOUR" OF THE CEREBELLUM

\title{
REPORT ON TWO CASES OF DIFFUSE HYPERTROPHY OF THE CEREBELLAR CORTEX WITH A REVIEW OF NINE PREVIOUSLY REPORTED CASES
}

\author{
BY \\ D. R. OPPENHEIMER \\ From the Department of Neurosurgery, Maida Vale Hospital for Nervous Diseases, London, and the \\ Department of Human Anatomy, Oxford
}

It sometimes happens that a patient shows clear signs of an expanding lesion in the posterior cranial fossa, but at operation no neoplasm can be found. The cerebellum may appear vaguely abnormal, but biopsy is inconclusive, except for the fact that the tissue is not gliomatous. One possible cause of this occurrence is a condition in which the neural elements of the cerebellar cortex undergo certain characteristic changes resulting in an increase in bulk of some part of the organ, and hence in the clinical picture of a posterior fossa tumour. The pathological nature of these changes, which are remarkably constant from case to case, is still not certain. It is probably not neoplastic, though the previous authors who have described the condition are not agreed on this.

Two cases of this condition are described here, with case histories and pathological findings. An account is also given of nine previously reported cases, all showing a similar pathology, and a tenth showing a somewhat different picture, which, there is reason to think, may represent an earlier stage of the same disease. Of these 12 cases, three died from the progress of the disease ; five died during or shortly after operation; two died from other causes; and the remaining two were successfully operated upon.

The first of the two cases to be reported on is the second in the series to survive operation. On that account, it is thought worth while to describe his vicissitudes in some detail.

\section{Case Reports}

History.-The patient, S. S., was a 52-year-old Jewish labourer. Eighteen months before admission he had the first of a series of episodes of sudden, severe bifrontal headache of a stabbing quality, accompanied by profuse sweating, loss of vision, and a sudden weakness of the legs, which buckled under him. Apparently he did not lose consciousness. Vision returned after a few minutes, and he would be well and fit for work after a short rest. There was no feeling of dizziness ; there were no convulsive movements and no incontinence of urine. Similar attacks occurred at the rate of two or three a week for the following four months. There was no headache apart from the attacks.

In October, 1952, he was investigated in another hospital, where he was found to have papilloedema with haemorrhages in both retinae, impaired visual acuity, and constriction of the peripheral visual fields; there was nystagmus on lateral gaze to both sides, but no other cerebellar signs were observed, nor any evidence of long tract damage. Lumbar puncture showed a pressure of $300 \mathrm{~mm}$. of water ; the fluid was clear, and contained two lymphocytes per c.mm. and $55 \mathrm{mg}$. of protein per $100 \mathrm{ml}$. Ventriculography was proposed, but the patient demurred, and was discharged.

There were no further attacks until the last few weeks before admission to the Maida Vale Hospital in September, 1953, during which the patient had felt weak and collapsed three times, but did not lose vision. On the other hand, headaches, unassociated with attacks, were becoming more frequent, and were occurring two or three times a week, usually in the early morning. Their quality was still sharp and stabbing, but the site had shifted from the forehead to the left temple and back of the head. Only once was there an associated nausea and retching.

Other symptoms had appeared over the preceding few months. Feeling had been impaired in the right hand, starting with the thumb and spreading to the other fingers, and the patient was having difficulty in fine movements such as fastening buttons. Several times the right hand had trembled uncontrollably for a few seconds, and hád once gone into spasm in a clutching attitude. Further, the patient complained of gradually failing vision and hearing over the past year or two, and of increasing difficulty - his wife confirmed this-in day-today memory. The wife added that he had " grown old" in the last year or two ; otherwise there was no clear history of mental deterioration. There were no other symptoms.

On admission, the positive physical findings were a blood pressure of $160 / 105 \mathrm{~mm}$. $\mathrm{Hg}$; some slowness of comprehension but otherwise no definite mental change ; bilateral papilloedema with haemorrhages; a visual 
acuity of $6 / 36$ on the right and 6/12 on the left, both corrected, and a fairly uniform constriction of the peripheral visual fields on both sides ; lateral nystagmus, more marked to the right ; some deafness, of middle ear type, more marked on the right; a little intention tremor and dysmetria of the right hand, with impairment of quick alternating movements on that side ; slight impairment of skin sensibility, of two-point discrimination, of vibration and position sense, and of stereognosis in the right hand; gait was steady, and there were no signs of pyramidal damage.

Plain radiographs of the skull showed only doubtful thinning of the dorsum sellae. The internal auditory meatuses were normal. Electroencephalography gave a record suggestive of a tumour in the posterior fossa, and tests of labyrinthine function, performed by Mr. W.S. McKenzie, pointed to a right-sided cerebellar lesion.

Ventriculography was performed on October 21. Pressure was high, and the films showed a fairly gross hydrocephalus involving the lateral and third ventricles. The fourth ventricle was dilated and shifted upwards and to the left, indicating a low right-sided cerebellar tumour.

The ventricular fluid was quite normal.

On the same day, Mr. Valentine Logue explored the posterior fossa through a right occipital flap. No tumour could be seen arising from the meninges or in the cerebello-pontine angle, and none was felt on needling the cerebellum ; on the other hand, the right cerebellar tonsil was grossly enlarged, herniating into the foramen magnum, compressing and indenting the medulla, and blocking the outlet of the fourth ventricle. The lamellar pattern appeared normal, though the folia were uniformly thickened. The surface of the cerebellum was unusually pale. Small incisions were made in its substance without revealing anything more than a slightly irregular firmness of the cerebellar white matter. A small piece was taken for biopsy. Closure of the dura was not practicable, owing to bulging of the cerebellum, and the patient was left with the decompression and external ventricular drainage, which was continued for seven days.

In the biopsy specimen the most striking feature was the condition of the small blood vessels. These showed a generalized proliferation, especially immediately below the pia, but also in the underlying tissue. In two places this amounted to angiomatous nodules, visible with the naked eye (Fig. 1). The vessel walls were diffusely calcified. The pia itself was thickened, and in places folded double in deep clefts in the nervous tissue. This tissue was quite unlike normal cerebellum. Immediately below the pia there were myelinated nerve fibres and a number of glial nuclei. Beyond this there were patches containing nerve cells of various shapes and sizes, but none were characteristic of the cerebellar cortex. The picture was not considered to be a neoplastic one ; further than this, with the limited material to hand, it was not possible to go.

After a week, during which the patient's condition was satisfactory, with virtually unchanged neurological signs, ventriculography was repeated. This showed

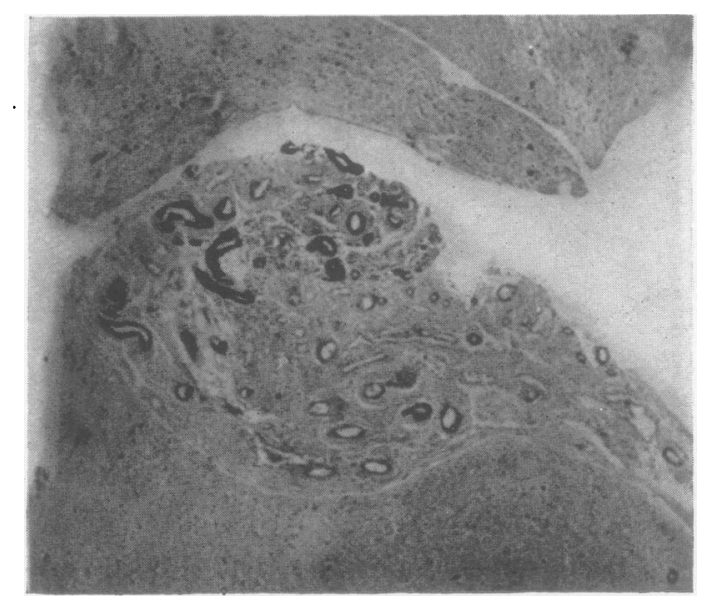

FIG. 1 (S. S.).-Angiomatous vessels, with calcareous incrustations, in thickened pia. H. \& E. $\times 40$.

nothing new. After this, the patient's condition deteriorated sharply; he became drowsy, confused and disorientated, sweated copiously, and developed retention of urine. During the next few weeks he slowly recovered his equilibrium; cerebellar signs were becoming less obvious, and there had been a complete recovery of the sensory deficit in the right hand. Vertebral arteriography on November 18,1953, showed that the medulla was still displaced to the left, and that the right posterior inferior cerebellar artery was larger than normal, but there was no sign of tumour vessels.

Meanwhile the occipital decompression began to bulge; the patient suffered frequent headaches, and repeated ventricular and lumbar taps showed a high and mounting pressure, and it was decided to re-explore.

On November 27, a full cerebellar flap was turned, and a larger exposure obtained. Again no neoplastic mass was found, but the medulla was still compressed and displaced to the left by the huge, herniating right tonsil, and the outlet of the fourth ventricle was blocked, partly by an oversized posterior inferior cerebellar artery. In order to relieve the obstruction, the offending tonsil was amputated at its base and the opening of the fourth ventricle enlarged. The dura was then closed with the aid of a patch of the lining membrane of the sac which had formed beneath the neck muscles. The pathological description of the excised tonsil will be deferred to the next section.

The patient was up and about after two weeks, during which there were episodes of mental confusion, retention of urine, troublesome hiccups, and irregular pyrexia.

Over the next two months the patient's condition gradually improved, though at first there was some unsteadiness in walking, with a tendency to stagger to the right. There were no further headaches, and the patient felt fairly well. However, the meningocoele in the neck reasserted itself. Lumbar punctures were frequent, and consistently yielded a yellowish fluid containing several hundred cells (many of them histiocytes) and 300 to $500 \mathrm{mg}$. of protein, with a pressure of 
about $180 \mathrm{~mm}$. Clearly the cerebrospinal circulation was still inadequate, and it was decided to perform a shortcircuiting operation.

Ventriculography on January 27, 1954, showed a dilated, but now centrally situated, fourth ventricle. A right frontal flap was turned, and an anterior ventriculostomy was performed, using a short length of $2 \mathrm{~mm}$. bore polythene tubing.

Post-operative progress was uneventful. The neck swelled once more, but after $250 \mathrm{ml}$. had been withdrawn, and a pressure bandage applied, it remained flat.

The patient was discharged on February 10, 1954, feeling a good deal better than when he came in, and with no particular symptoms. He had lost four of his 17 stones, and the blood pressure was $130 / 80 \mathrm{~mm}$. $\mathrm{Hg}$. He failed dismally in simple arithmetic tests, and was slow in comprehension, as he had been before; otherwise he was rational and at home in the world. Both vision and hearing had improved. Papilloedema had subsided, leaving signs of optic atrophy on the right. There were virtually no cerebellar signs.

Fourteen weeks later he was seen as an out-patient, having been working as a manual labourer for three weeks. Mentally, he was more alert, and performed arithmetical tests readily. The optic discs were flat, and vision in both eyes had improved. There was no nystagmus, or any other sign of cerebellar damage. The only symptom was a recurring pain (apparently of muscular origin) in the back of the neck.

A year later (13 months after the final operation) this symptom had largely cleared; otherwise, the patient's condition was virtually unchanged.

Pathological Findings.-On naked-eye inspection, the excised tonsil showed recognizable cerebellar foliation,

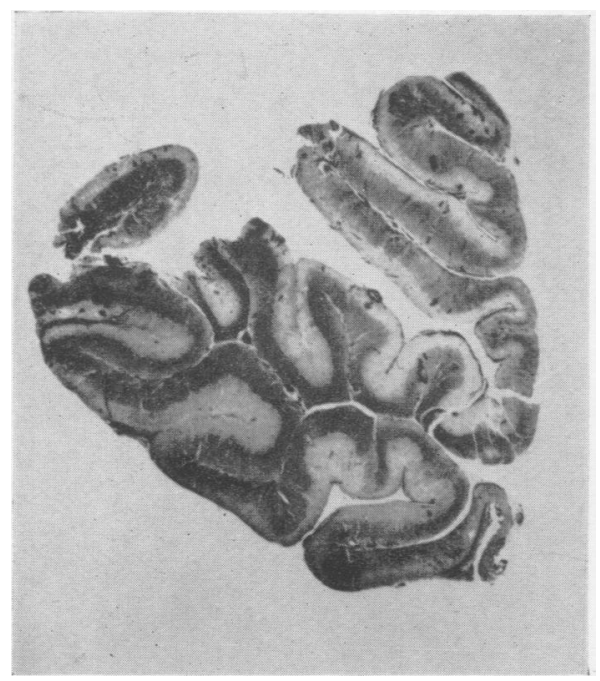

FIG. 2 (S. S.).-Section of excised tonsil. Loyez. $\times 3$. The myelinated layer (dark) has a pial covering. Except for a small area on the left, the central white matter has disappeared.

FIG. 3.-Enlargement from Fig. 2, showing pial covering of myelinated layer. $\times 30$. but the folia were abnormally broad, and the colour unusually pale. On section, the medullary centre was seen to be lacking, so that the tissue appeared as a much-folded sheet, 1 to $2 \mathrm{~mm}$. thick, with a pial covering on one surface. Without this, there would have been difficulty in distinguishing between the inner and outer surface of the tissue (Figs. 2 and 3 ).

The structure of the main tissue was uniform almost throughout. It contained two clearly defined layers of approximately equal thickness-an outer one consisting mainly of nerve fibres, and an inner one composed mainly of nerve cells of unusual types. Since no normal cerebellar tissue was included in the specimen, these layers could not be identified with the molecular and granular layers, though the findings in other reported cases make this identification probable.

No lining membrane could be seen on the inner surface of the tissue. In places where the convex aspect of a fold was on the outside, a few strands of nerve fibres, mixed with glial elements, could be seen separating the infolded cellular layers; elsewhere, there were narrow clefts containing blood. Where the convexity of a fold lay inside, the cellular layer stopped abruptly, forming a fairly smooth edge. As in the first biopsy, proliferation of small blood vessels was observed, with basic-staining granules studded along their walls.

Stains for myelin and silver impregnations displayed a fairly uniform disposition of the fibres in the outer layer. These could be seen arising from the cells in the inner layer, running vertically outwards, singly or in small bundles, branching, and thereafter running parallel to the surface along the direction of the folia (Fig. 4). Thus, in sections taken along a folium, there was a criss-cross effect, while in sections taken across a folium one saw mainly vertically-running fibres with

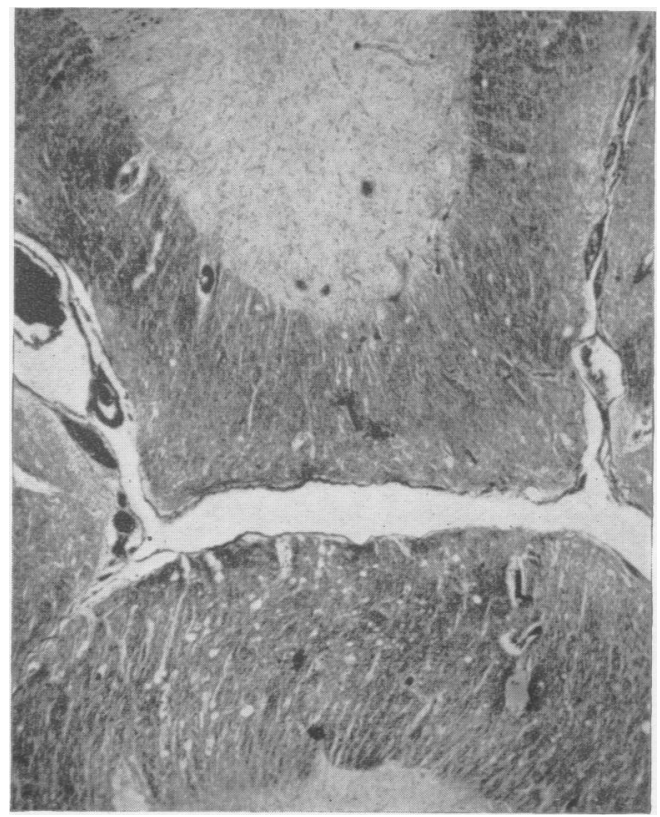




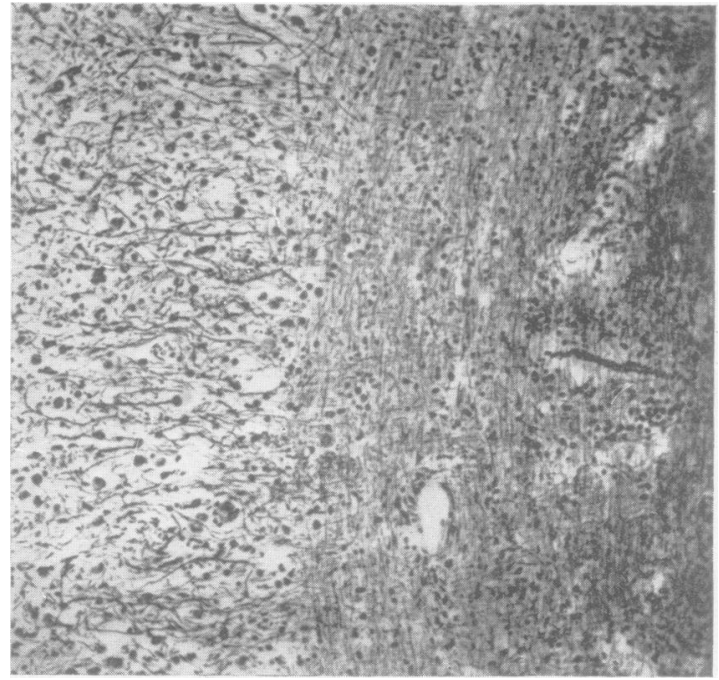

Fig. 4 (S. S.).-Arranzement of fibres in cellular layer (on left) and myelinated layar (on right). Bielschowsky. $\times 70$.

a stipple of cross-cut fibres between. The fibres were of varying thickness, and a large proportion were myelinated. Nothing resembling Purkinje dendrites was seen. This layer also showed glial nuclei, mainly rounded, about $6 \mu$ in diameter, greatly in excess of the number usually found in the molecular layer. In places, these cells occurred in closely packed clusters, elsewhere in short

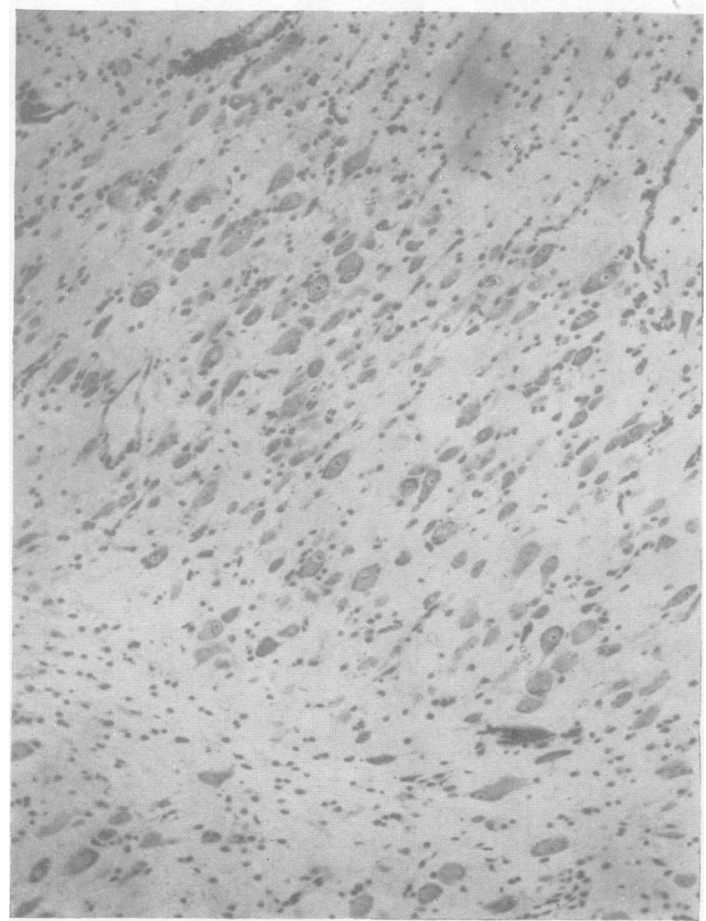

chains, an arrangement typical of oligodendrocytes. Their presence can be confidently related to the presence of myelin sheaths in this layer. A few isolated nerve cells were seen, similar to those found in the inner layer. Small blood vessels were abundant, many showing basophilic incrustations, which were shown by von Kossa's method to consist of calcium salts.

The cells which composed the bulk of the inner layer, though they showed much variation in size, shape, and staining properties, were for the most part clearly identifiable as nerve cells (Figs. 5 and 6). The cell bodies were round or polygonal, the larger ones up to $45 \mu$ in diameter, the smaller ones about $8 \mu$, and averaging about $16 \mu$. Many of them had long, tapering cytoplasmic processes, ending in a thick fibre. Nuclei were round, sausage-shaped, or indented, and averaged about $10 \mu$ in diameter. The cell bodies contained Nissl substance ; the nuclei contained a little chromatin, and well marked, usually eccentric nucleoli. In some places there were many degenerate-looking forms, some with diffusely dark-staining cytoplasm, others with what appeared to be nuclear inclusion bodies alongside the darkerstaining nucleoli (Figs. 7 and 8). Occasional dumb-bell cells with two nuclei were seen, but there were no mitotic figures.

The fibres arising from these cells, many of which were very thick, ran in an irregular network between the cells before collecting into small bundles which passed vertically into the outer layer.

Glial nuclei were present in the inner layer, but not so abundantly as in the outer one. In addition, there were

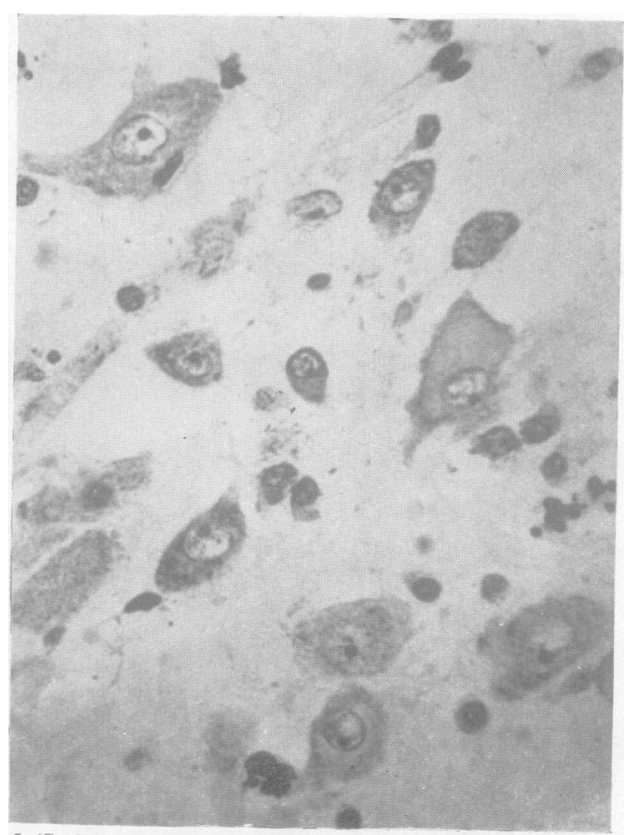

FIG. 5 (S. S.).-Top right : radially arranged glial nuclei in outer layer. Lower left : remains of white lamina. Between : layer of nerve cells. Nissl. $\times 70$.

FIG. 6 (S. S.).-Group of nerve cells. Nissl. $\times 280$. 


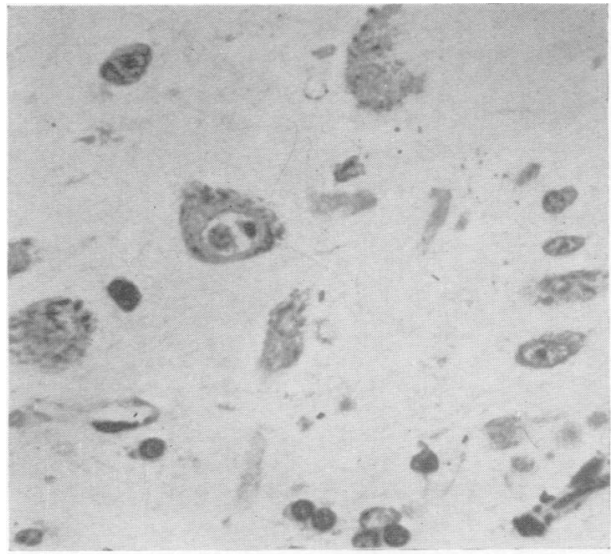

FIG. 8

FIG. 7 (S. S.).-Cell degeneration in the inner layer. Nissl. $\times 280$.

FIG. 8 S. S.).-Cells of inner layer, one containing a nuclear inclusion body. Nissl. $\times 280$.

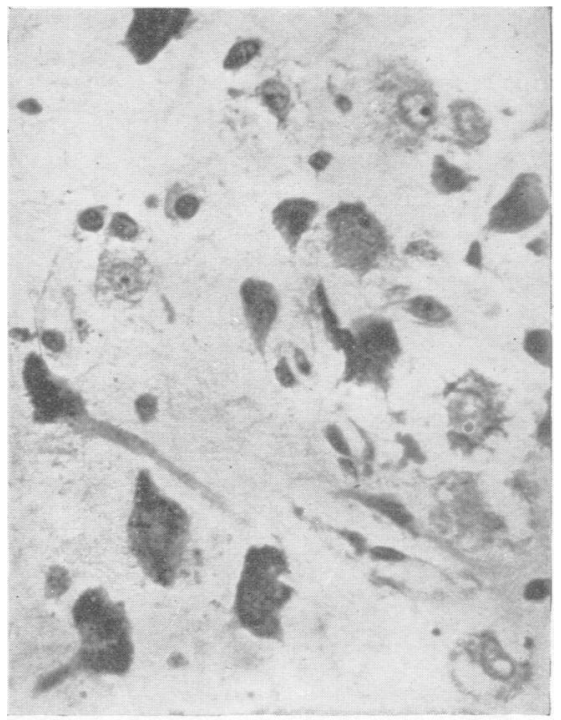

FIG. 7 occasional very large cells (up to $90 \mu$ in diameter), seemingly of glial type (Fig. 9). These probably correspond to the Alzheimer cells observed by Bielschowsky and Simons (1930) in one of the cases which they describe. Specific staining for glial fibres revealed a mild gliosis in one or two places in the outer layer, and again in the clefts which corresponded to the vanished medullary centre.

In the inner, cellular layer one occasionally saw small,

FIง. 10

FIG. 9 (S. S.).-Large cell, probably of glial type; two nerve cells on right. Loyez. $\times 280$.

FIG. 10 (S. S.).-Area containing granule cells, and suggestion of empty basket formations. Bielschowsky. $\times 280$.

FiG. 9

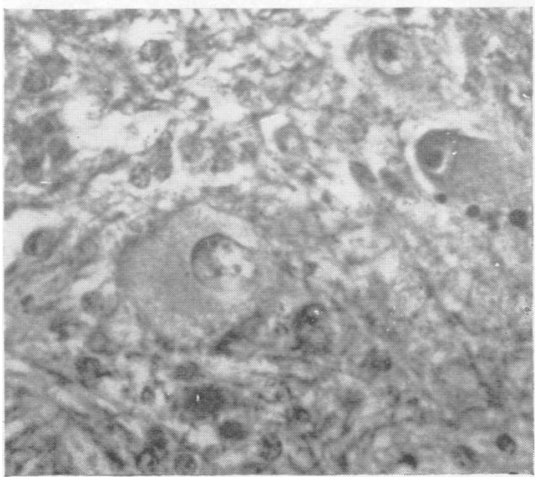

deeply staining nuclei which closely resembled those of normal granule cells : otherwise, these elements were totally lacking, except for one small area where granule cells were abundant, forming a thin but recognizable layer. Within this there was a medullary centre of reasonable thickness; and at the margin between the granule-containing layer and the myelinated outer layer, there were appearances suggestive of basketformations surrounding empty pockets, where one might

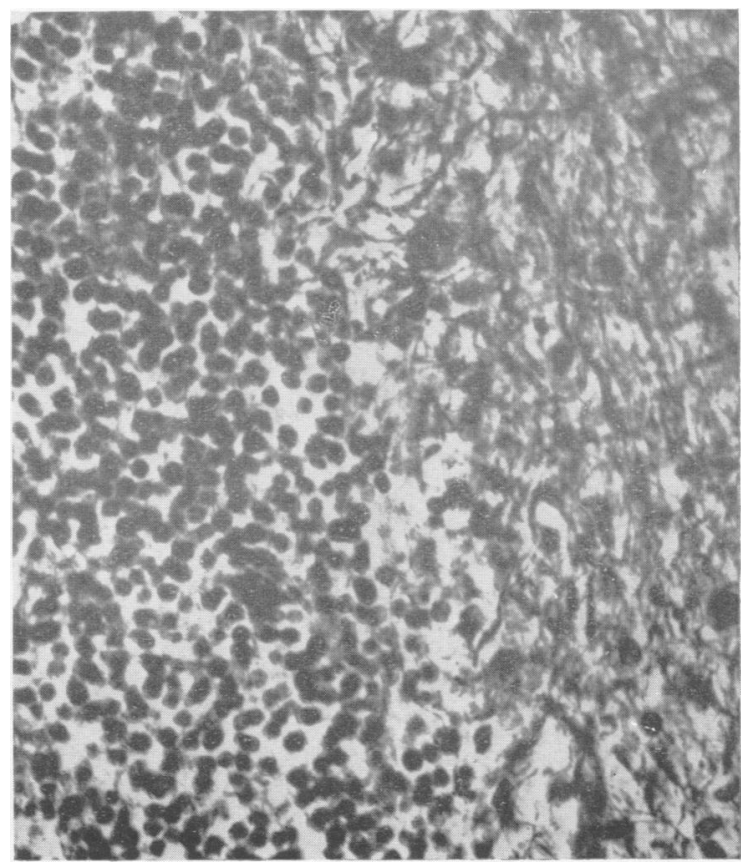


fancy Purkinje cell bodies to have been (Fig. 10). Unfortunately, it was not possible to trace the transition from this comparatively normal area to the abnormal one.

The material for the second case was supplied by the kindness of Mr. W. R. Henderson.

History.-The patient, J. D., was a man of 21 , who presented in January, 1950, with a five-month history of vertiginous attacks, during one of which he fell forwards and could not get up. For three months there had been attacks of blurring of vision, which were becoming more frequent ; for two months, occasional unsteadiness of gait, occasional tinnitus, one attack of vomiting, but no headache. On examination, he had severe bilateral papilloedema, and slightly impaired vision on the left, and no other physical signs. A diagnosis of posterior fossa tumour was made, and an exploration was undertaken. The patient died shortly after the operation, probably as a result of accidental damage to the brainstem.

Pathological Report.- Necropsy showed no abnormality outside the brain. Here there were signs of raised pressure-flattened cerebral convolutions, moderately dilated lateral ventricles, and tonsillar herniationand a good deal of subarachnoid blood.

Externally, the cerebellum showed relative enlargement of the right hemisphere. Foliation was of more or less normal pattern, but in some areas on the right the folia were increased in breadth, up to about twice the normal size. This was most marked in the area behind the fissura prima on the tentorial surface (Fig. 11). Nothing abnormal was seen in the superficial blood vessels.

The cut surfaces showed a normal cerebellar pattern on the left. On the right, the lateral part of the hemisphere showed a thickened $(2.5$ to $3.5 \mathrm{~mm}$.) folded cortex, paler than normal cortex, devoid of central white matter, and therefore unconnected with the white matter surrounding the cerebellar nuclei. After two parallel cuts, this abnormal tissue fell away readily from the main block. The white matter, which was less in quantity than on the left, appeared to be connected only with normal areas of cortex. The midline of the vermis was shifted half a centimetre to the left, and there was a corresponding distortion of the brain-stem (Fig. 12).

Blocks were cut for sectioning from the brain-stem, from the area containing the cerebellar nuclei, and from both hemispheres, including a "transitional " area on the right. Nissl, Weil, and Bodian stains were mainly used.

The histology of the frankly diseased tissue corresponded closely with that of the previous case, except that the blood vessels in this case appeared normal. There was, as before, a cortex about $2 \mathrm{~mm}$. thick, clearly divided into an outer layer, consisting of myelinated and non-myelinated fibres, and an inner layer of abnormal nerve cells, with no underlying white matter (Fig. 13). The fibres in the outer layer, as before, left the inner layer in small bundles and coursed first radially then horizontally along the folium (Fig. 14). A few nerve cells were seen in the outer layer, but glial nuclei were not present in excess, and no "chains" were seen. The cells of the inner layer were similar to those in the first case, with diameters of 8 to $35 \mu$, averaging about $12 \mu$, and included a rather larger proportion of tadpole-shaped forms (Fig. 15). No mitotic figures were seen.

The area of transition from normal to abnormal cortex (Figs. 16 and 17) showed special features. First, there were signs of myelination in fibres of the innermost part of the molecular layer, running horizontally and at right angles to the folium, which were accordingly identified as basket-cell fibres; also in fibres running in the direction of the folium in the outermost part of the molecular layer, these being identified as granule cell fibres. A similar picture was found in one or two places on the left side (Fig. 18).

The cells themselves appeared normal in these areas, and Purkinje cells were present in normal numbers. There were several areas (mostly at the convexity of a folium) where the granular layer was thicker, the granule cell nuclei stained less deeply, and Purkinje cells became sparse. Surviving Purkinje cells showed signs of degeneration, such as "torpedo" formations in their processes (Fig. 19) and in between them were empty basket-formations, which presumably marked the sites of extinct Purkinje cell-bodies. Next, abnormal cells began to appear in the granular layer, and Purkinje cells disappeared; and finally recognizable granule cells disappeared, and all the cells were of the abnormal type. Since other authors, in describing this transition, have regarded the abnormal cells as tumour cells " infiltrating " into the granular layer, it is worth emphasizing that one cannot discern a clear morphological distinction between granule cells and the abnormal types. In the transition area, one can pick out cells forming a concontinuous series from one to the other (Fig. 20).

The changes in the central white matter are not apparent until the transition zone is reached. Here, it becomes considerably thinner, as the cortex becomes thicker, and one must follow the cortex for a considerable distance before the white centre finally vanishes.

Examination of the dentate, pontine, and olivary nuclei showed no definite changes, but it was difficult to compare the two sides on account of the gross distortion of these areas.

\section{Review of Previously Reported Cases}

In this section summaries will be given of the individual case histories, on account of their practical interest and of the relative inaccessibility of some of the literature. The pathological findings, which are closely similar, will be summarized together.

Case 1.-This was described by Lhermitte and Duclos (1920) and is believed to be the first reported cases.

Male, aged 36. For one year, hearing impaired on left; for 10 months, occipital headaches. For one month, dizzy attacks, with falling; unsteady gait ; mental deterioration, with confusion and loss of memory and 


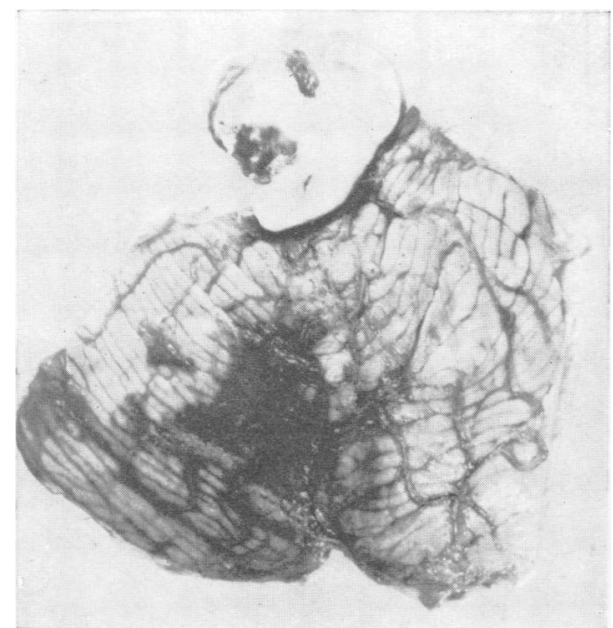

FiG. 11 (J. D.).-View of tentorial surface of cerebellum. Thickened folia can be seen on the right. A portion of the right hemisphere has been cut away. $2 / 3$ natural size.

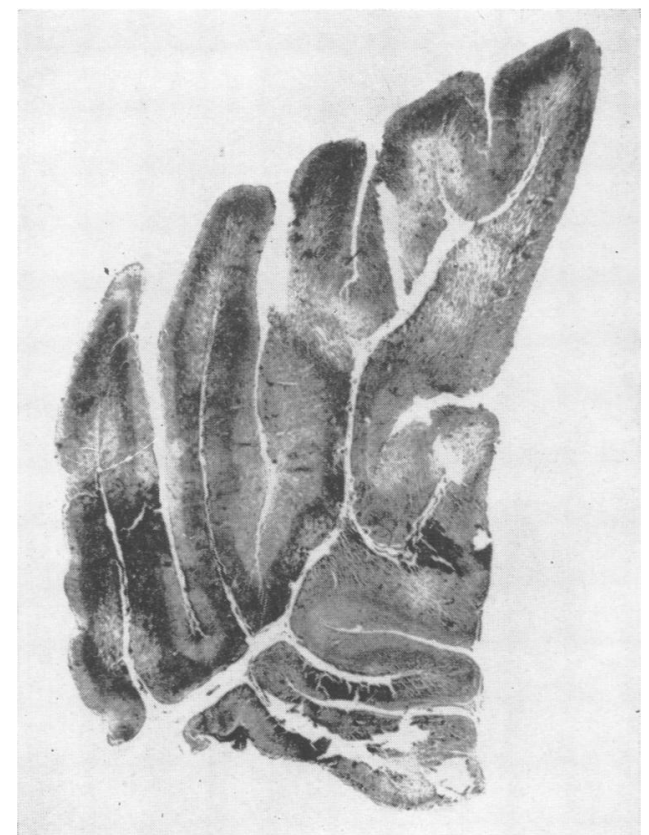

FIG. 13 (J. D.).-Section of diseased tissue. What appears to be the outside is in fact the inner surface of the cortex. There is a pial lining to the central cleft. Weil. $\times 3$.

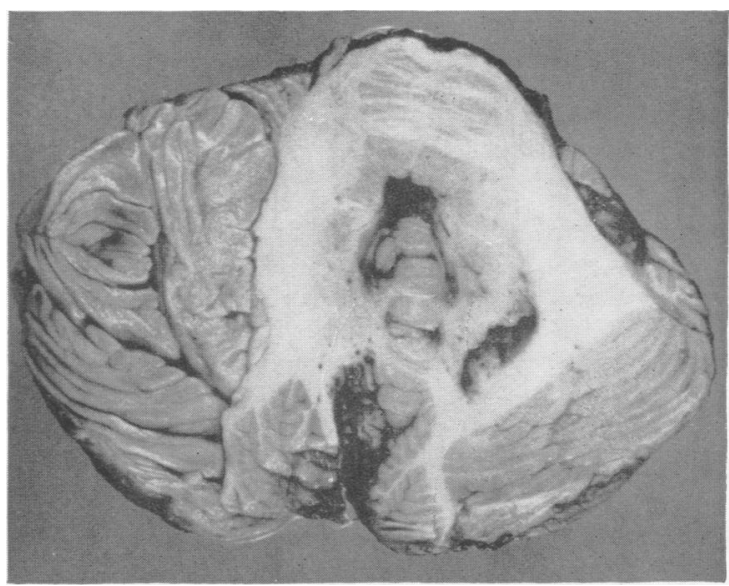

FIG. 12 (J. D.).-Cut curface, looking rostrally. There is a deep cleft between the diseased tissue on the right and the white matter of the hemisphere. $2 / 3$ natural size.

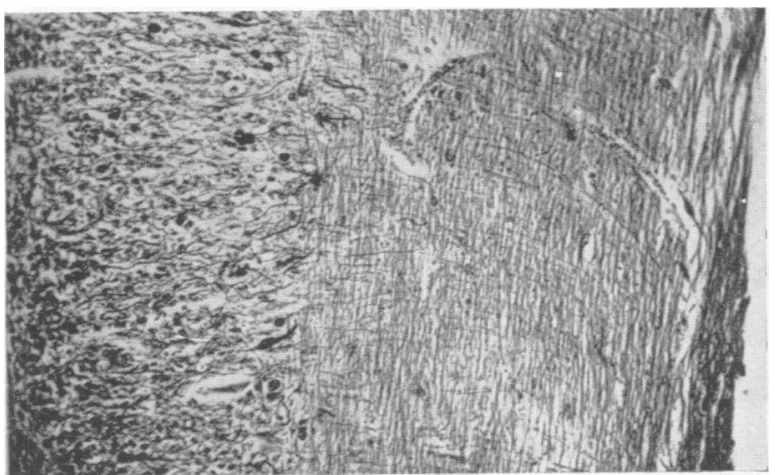

FIG. 14 (J. D.).-The disposition of fibres in the granular layer (left) and the molecular layer (right). Bodian. $\times 67$.

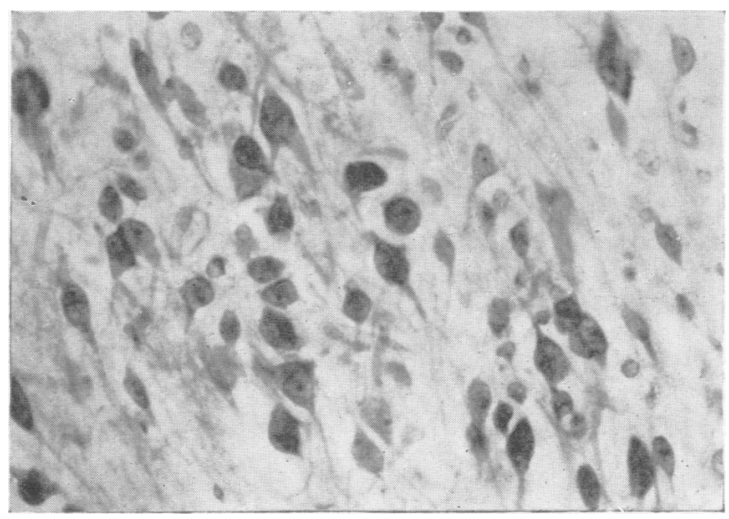

Fig. 15 (J. D.).-Cells in the granular layer. Nissl. $\times 290$. 


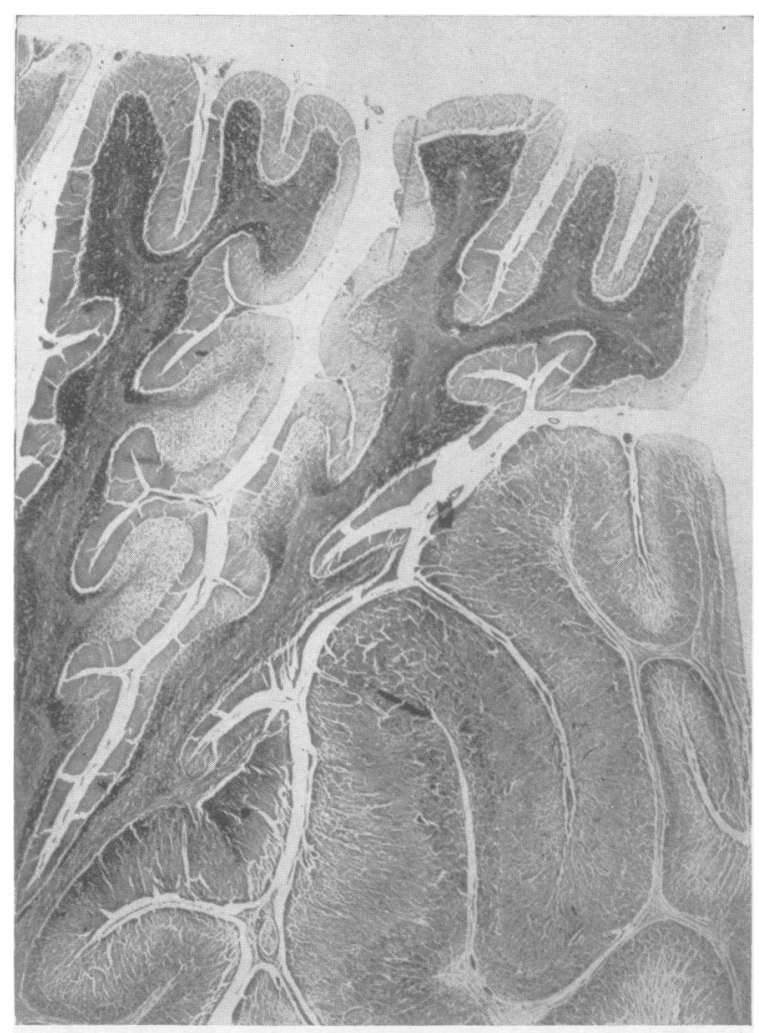

FIG. 16

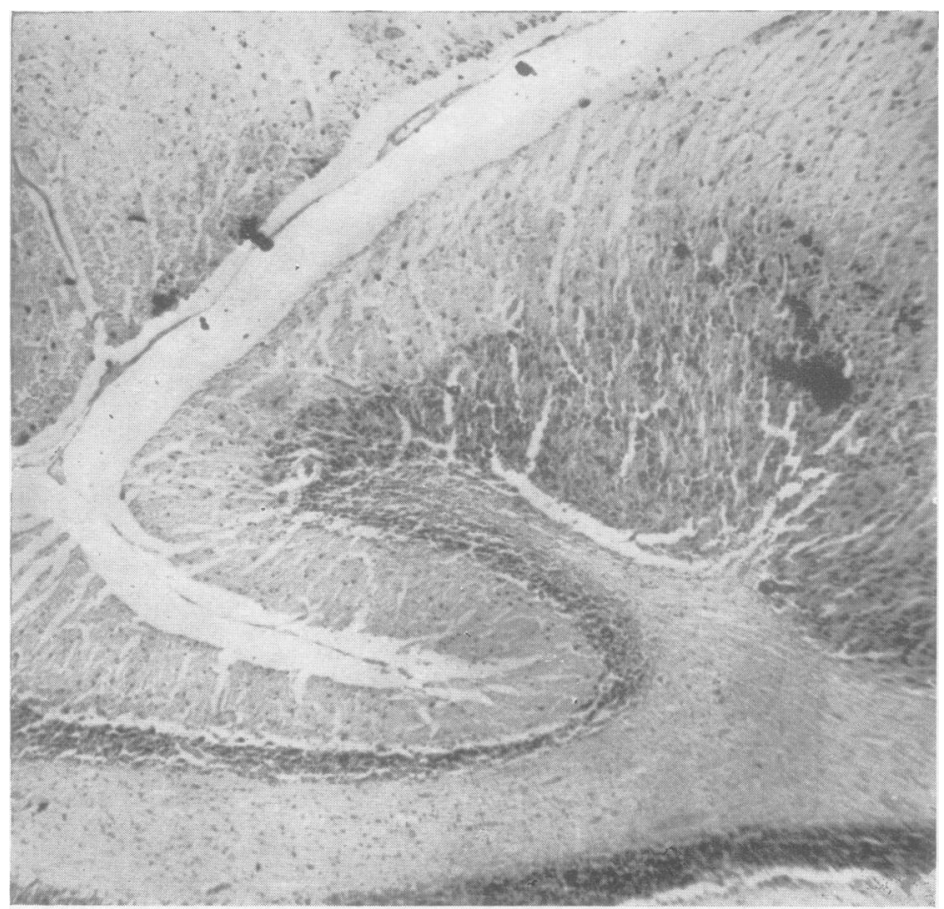

FIG. 17

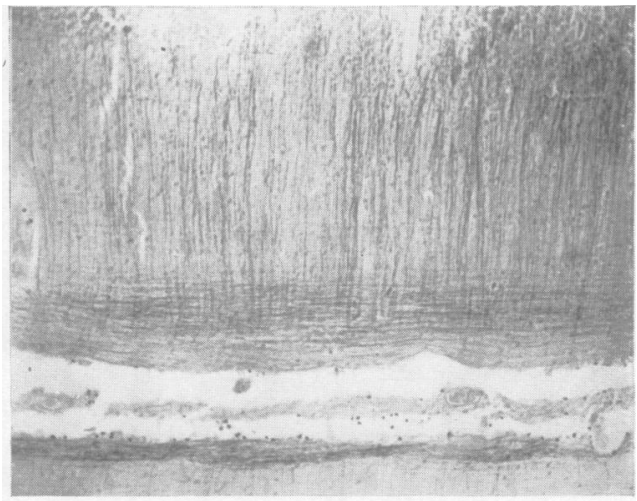

FIG. 18

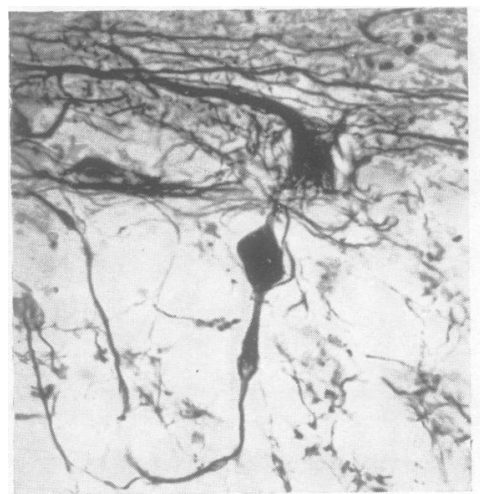

FIG. 19

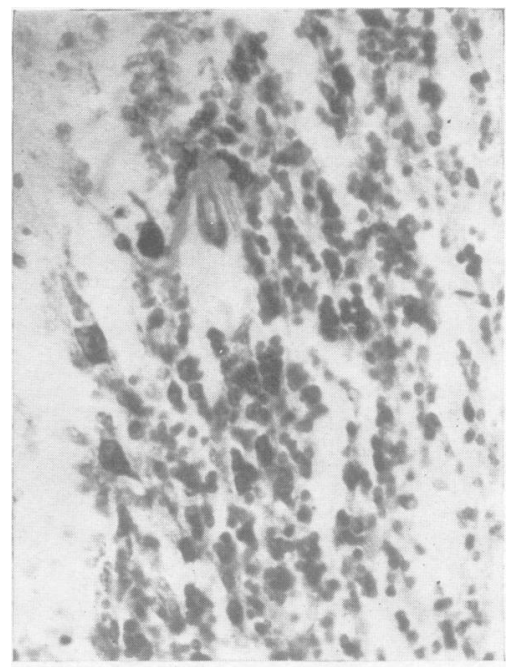

FIG. 20 
concentration. On admission, confused, disorientated, dysarthric; gross cerebellar ataxia of four limbs; nystagmus to right and left ; tendon reflexes increased. Sensation was normal.

Lumbar puncture showed a normal pressure, with normal cells, but increased protein in the fluid. The Wassermann reaction was negative. After a week, the patient went rapidly downhill, with increasing headaches, vomiting, and mental distress. He died in coma.

Case 2.-This was described in its general aspects by Schmidt (1926). The cerebellum was examined and reported on by Hallervorden, and his findings presented in a paper by Bielschowsky and Simons (1930).

Male, aged 45. Congenital malformation of skull. Ten years before admission sustained a head injury. Unconscious for a day ; subsequently had left hemiplegia, which cleared partially. From this time on, subject to headaches and dizzy attacks. Five months before final illness, treated for rheumatic pains in one arm. Observed to have a left facial palsy. Later became bedridden, and was found to have bilateral papilloedema. From this time on, increasing headaches, with vomiting; motor disturbances, with neuralgic pains in right arm and leg. Palsy of left vocal cord and atrophy of left sternomastoid. Increasing marasmus and death from pneumonia.

Case 3.-This case was reported in great detail by Bielschowsky and Simons (1930).

Female, aged 20. Born with six digits on each hand. Ulnarmost digits amputated in infancy. For two years, unsteadiness of gait; occasional dizzy attacks and fainting fits; paraesthesiae in all limbs; some supraorbital pain ; few headaches, never severe ; some retching, no vomiting. Unsteadiness getting steadily worse.

Physical findings included bilateral papilloedema, coarse nystagmus on right and left gaze, and well marked cerebellar signs in the limbs, mainly on the right. Radiographs showed evidence of raised intracranial pressure, confirmed by lumbar puncture. The patient was referred for surgery, with a diagnosis of right-sided posterior fossa tumour, but died on the table after the bone had been removed and before the dura was opened.

Case 4.-This case was described by Foerster and Gagel (1933) as one of a series of ganglion cell tumours of the brain.

FIG. 16 (J. D.).-Section of transition area. Observe (a) thickening and altered staining reactions of the granular layer at various points of convexity in the normal area; $(b)$ attenuated white matter in diseased area. H. \& E. $\times 9$.

FIG. 17 (J. D.).-Transition area. The granular layer in the lower left corner is almost normal, and Purkinje cells are present. Nissl. $\times 42$.

FIG. 18 (J. D.).-Myelinated granule cell fibres in the left hem.isphere. The cellular picture in this area is normal. Weil. $\times 67$.

FIG. 19 (J. D.).-Degenerating Purkinje cell near the transition area, showing "torpedo" formation. Bodian. $\times 290$.

FIG. 20 (J. D.).-Mixture of granule cells and abnormal types near the transition area. There are three degenerating Purkinje cells. Nissl. $\times 290$.
Female, aged 43. Miultipara. Rheumatic valvular disease. For one year, headaches, mainly right frontal. Numbness of right side of face ; giddy attacks ; vomiting. For two weeks, clouding of vision. Physical examination showed severe bilateral papilloedema, impairment of right trigeminal function and right facial paresis. No cerebellar signs. Three months later, increased papilloedema and visual impairment, but still no cerebellar signs. Ventriculography showed dilated lateral ventricles. After this there was definite nystagmus to the right. Exploration of the posterior fossa had to be stopped after removal of the bone, as the patient went into extensor spasm and stopped breathing for a time. Six days later a second attempt was made. The dura was tense but relaxed and pulsated after ventricular puncture. Opening of the dura revealed a grossly swollen left cerebellar hemisphere, with broad, flattened, greyishyellow gyri. The whole infero-lateral part of the hemisphere was excised. Respiratory arrest, and death on the table.

\section{Case 5.-Barten (1934) reported this case.}

Female, aged 37. For seven years, dizzy feelings when standing up. Unsteady gait, getting worse. Two years later, following third pregnancy, marked increase of unsteadiness, and visual disturbances. Paraesthesiae and transitory weakness in right arm and leg. Eight months later, seen as out-patient ; coarse nystagmus, bilateral facial paresis, dysarthria; increased tendon jerks. No papilloedema. Lumbar puncture ; pressure normal, fluid normal. During the next few years there was gradual mental deterioration, and the patient was finally brought in, having been bedridden for six months and stuporous and confused for a few days. She had difficulty in swallowing, and had developed bronchitis. She died on the day after admission, from sudden central respiratory arrest.

Case 6.-Christensen (1937) described this case as one of a series of five ganglion cell tumours in the brain. This is her case 5 .

Male, aged 34. For six years, attacks of "pressure" feelings on both sides of the head associated with severe pain in the back of the neck, "flickering " in the temporal fields of both eyes, vomiting, and a feeling of weakness in the legs. Attacks occurred about once a month, and lasted about an hour. Over the past year, attacks had become more frequent, and sometimes led to unconsciousness. No symptoms between attacks. Physical signs included bilateral papilloedema, impairment of left trigeminal function, and a mild right facial paresis. There were no cerebellar signs or symptoms. Ventriculography showed a shift of the fourth ventricle and aqueduct to the left.

The posterior fossa was explored. The folia of the right cerebellar hemisphere were thickened and flattened. The consistency of the tissue resembled that of a cerebral glioma, but no definite tumour mass was found. The lateral third of the right hemisphere was resected. Recovery was complicated by a troublesome arachnoiditis, but 18 months later the patient was back at 
work, free from headaches. It has not been possible to trace his subsequent progress.

Case 7.-This case was reported by Heinlein and Falkenberg (1939).

Male, aged 23. Fractured skull as a child ; two days unconscious ; no sequelae. For the past two years, unsteady gait, tinnitus, giddy attacks, feeling of pressure. Symptoms steadily increased. For the past three weeks, severe headache with vomiting, and pain in the back of the neck. Impaired vision in left eye, impaired hearing in left ear. Physical signs included bilateral papilloedema and exophthalmos ; bilateral nystagmus ; impairment of all cranial nerves from 5 to 12 on the left; and marked cerebellar malfunction, especially on the right. Radiographs showed evidence of raised pressure. A simple posterior fossa decompression was performed but the patient died the following day from central respiratory arrest.

Case 8.-Duncan and Snodgrass (1943) reported this case.

Female, aged 27. Large head since childhood. At age 14, two fingers amputated for cavernous haemangiomata. One and a half years ago, one of two small nodules in scalp, present since birth, quickly grew to size of hen's egg. It was excised and found to be an angioma. From this time, began to suffer from frontal and occipital headaches, which grew steadily worse. Tinnitus in right ear. Later, sudden attacks of weakness, with falling, but no loss of consciousness. For eight months, diplopia and gradually failing vision; unsteadiness of gait ; attacks of " numbness" in face and elsewhere ; transient attacks of difficulty in speaking.

Physical signs included an unusually big head; bilateral severe papilloedema, with some loss of visual acuity and constriction of fields ; coarse nystagmus, right and left ; diplopia on looking to the right ; hypoaesthesia on left side of face; depressed gag reflex on left. Cerebellar signs in the limbs ; right and left dysdiadochokinesia, and reeling, broad-based gait, with tendency to fall to the right.

Lumbar puncture showed a pressure of $400 \mathrm{~mm}$., with a normal fluid. Skull radiographs showed thinning of the dorsum sellae, and ventriculography a symmetrical dilatation of the lateral and third ventricles; the aqueduct was kinked, and the fourth ventricle shifted forwards. At operation, both cerebellar tonsils were found to be herniating into the foramen magnum. The left cerebellar hemisphere was enlarged, but looked normal otherwise. The brain-stem was compressed, and pushed over to the right. No tissue was removed, and the patient was left with a simple decompression. After the operation she was disorientated; the temperature rose sharply, and she died the following day.

Case 9.- This case was reported by Alajouanine, Bertrand, and Sabouraud (1951).

Female, aged 26. For eight years, attacks of severe occipital headaches, with vomiting. These remitted for about a year, but returned, with the addition of transient muscular weakness and unsteadiness of gait. Later she developed tinnitus in the left ear, and a tendency to return fluids through the nose. Menstrual periods ceased. The blood Wassermann reaction was found to be positive, but arsenic and bismuth therapy produced no improvement. Three years later the physical signs included bilateral cerebellar ataxia, with nystagmus in all directions, right abducens paresis, palatal palsy, most marked on the right, and a "nasal" voice. Vision and fundi were normal; sensation normal; tendon jerks increased, but plantar responses flexor. The C.S.F. was normal, and the Wassermann reaction negative in blood and C.S.F. Symptoms steadily increased, and two years later the ataxia had made walking impossible. All limbs were now hypotonic, but there was bilateral ankle clonus and an extensor plantar response. In addition to the right sixth, the left fifth, seventh, eighth, ninth, tenth, and twelfth cranial nerves were affected, and cerebellar signs were more marked. The fundi were normal, and lumbar puncture showed a normal fluid. Ventriculography was proposed, but the patient suddenly died of respiratory arrest.

\section{Pathological Findings in the Previously Reported} Series

Except for one case, the cerebral hemispheres showed no pathological changes apart from nonspecific ones such as hydrocephalus and cerebral oedema. In every case there was marked enlargement of some part of one cerebellar hemisphere, and in some cases small patches were observed to be affected in other parts of the cerebellum. The pattern of the diseased folia is generally stated to have been normal, except for increase in their breadth. In most cases the affected areas were? observed to be paler than normal.

In every case, cross section showed a fairly even thickening of the cortex, with either a gross reduction or a complete absence of underlying white matter. Where white matter was lacking, many of the authors remark on the great difficulty in distinguishing between the outside and the inside of the tissue, a point which could generally be settled by the presence of pial membrane on one surface only. In one case (Case 4) it seems that the authors actually mistook the outside for the inside; at all events, if one makes this assumption, their descriptions and their excellent photographs tally in every important respect with the others in the series.

In every case the cortex showed two distinct layers, the outer one consisting mainly of nerve fibres, and the inner one of abnormal nerve cells. Recognizable granule and Purkinje cells were absent. In all cases where the transition zone was examined, it was found that the outer layer was continuous with the molecular layer, and the inner one with the granular layer. In all cases except 
one (Case 6, in which specific myelin staining was not performed) myelinated fibres were seen in the outer layer, running radially and tangentially in a criss-cross pattern. In five of the nine cases calcareous (or " pseudo-calcareous") incrustations were observed along the walls of the smaller blood vessels supplying the area.

Regarding the cells composing the inner layer, there is a general agreement that they belong to the ganglion cell series. They contain Nissl substance and have prominent nucleoli, and appear to be giving rise to the fibres which run in the outer layer. Apart from this, they vary greatly in shape and size, even in a single area. Cells with double nuclei or double nucleoli have been seen, but in no case have mitotic figures been observed. In spite of this, the general view, from the original authors onwards, has been that the cells are neoplastic in nature. Bielschowsky, who described the pathology in the greatest detail, regarded the cells as neuroblasts, exhibiting every stage of maturity; and this view has been held by several later authors. None of these, however, has dealt with the difficulty of regarding as neuroblasts cells with well developed, myelinated axons.

Glial elements, where they have been commented on, have usually been described as normal in quantity and character. Bielschowsky, however, observed giant glial cells, of the type described by Alzheimer in Wilson's disease, in Cases 2 and 3.

Bielschowsky and Simons and Duncan and Snodgrass are the only authors who report on the cerebellar connexions. The former found in Case 3 that all three cerebellar peduncles were reduced in size on the affected side, the dentate nucleus was missing on the same side, and the cells of the inferior olive roughly halved in number on the opposite side. Duncan and Snodgrass found the peduncles to be normal in size. (This, and other features in their description, suggest that the disease in Case 8 had not progressed as far as in most of the others.)

Special features were present in some of the cases : thus, Case 2 exhibited leontiasis ossea, with gross overgrowth of the left facial and cranial bones; some evidence of osteitis fibrosa ; a carcinoma in the left parotid region, with metastases in the liver, the spine, and the base of the skull; a large central "perithelioma" of the left frontal lobe; a carcinomatous deposit $1 \mathrm{~cm}$. in diameter in the lower part of the left cerebellar hemisphere; and two areas of ectopic cerebellar cortical tissue in the white matter of the front part of the same hemisphere, which was also the hypertrophied hemisphere. Cases 3 and 5 showed some widening of the central canal in the upper part of the cord.
Case 3 had polydactyly. Case 5 had an abnormally thin skull. Case 8 had multiple haemangiomata, and an unusually large head, with a brain weighing $1,960 \mathrm{~g}$.

Regarding the nature of the disease, the original opinion expressed by Lhermitte and Duclos (1920) was that it was a combination of a congenital malformation and a ganglion cell neoplasm, possibly arising from precursors of Purkinje cells. They named it " diffuse ganglioneuroma of the cerebellar cortex". Bielschowsky and Simons (1930) were frankly bewildered. They suggested, successively, such terms as " neurocytic blastoma", " hamartoma", "hamartoblastoma", without reaching a decision. After discussing the embryology of the cerebellum, they concluded that the absence of granule cells, which are normally derived from the transitory superficial cortex, and the presence of Purkinje-like cell bodies, presumably derived from the ventricular cell layer, provided the main clue. They therefore suggested that the condition was " an experiment of nature, which shows us how the cerebellum develops when the transitory superficial cortex is lacking, and the construction of the cortex is effected solely from the ventricular germinal material ". They were also disposed to relate the condition to the concomitant congenital abnormalities-polydactyly and hydromyelia in Case 3, and leontiasis, heterotopia cerebelli, and tumour proneness in Case 2.

Foerster and Gagel (1933) pointed out the similarity of the cellular picture with that of ganglion cell tumours elsewhere in the brain, and agreed with Bielschowsky and Simon that the condition is neoplastic, probably consisting of cells of the Purkinje family, and arising on the basis of a developmental anomaly. They called it "gangliocytoma with a dysplastic basis". A similar view was held by all the subsequent authors except Duncan and Snodgrass (1943), who broke new ground by pointing out that the course of the fibres in the molecular layer of the diseased cortex is in fact the normal course of granule cell axons. From this, they argue that the abnormal cells, which give rise to these fibres, are hypertrophied granule cells, myelination being a natural consequence of the hypertrophic enlargement of their axons. The abnormal cells seen scattered in the molecular layer, they suggest, may be similarly hypertrophied stellate cells. They do not commit themselves further, and do not explicitly accept or reject the embryological and neoplastic theories. They head their paper " Diffuse Hypertrophy of the Cerebellar Cortex", but finally apply the label " Myelinated Neurocytoma". 


\section{Spiegel's Case}

Finally, there is a case reported by Spiegel (1920) which, though not displaying all the typical features of the cases hitherto described, is of interest partly because of its analogies with Case 2 and with the second of the cases reported in this paper, and partly because it may conceivably represent an earlier, pre-clinical stage of the same disease.

The cerebellar abnormalities were discovered in the routine necropsy on a man of 22 , a victim of pulmonary and intestinal tuberculosis, who had never exhibited any neurological symptoms or signs. There was leontiasis ossea affecting the right side of the skull. The right cerebellar hemisphere was unevenly enlarged, and certain anomalies of the lamellar pattern were observed, which were held to demonstrate an arrested development, the stage of arrest being around the fifth month of intra-uterine life.

Serial transverse sections were taken of the whole cerebellum and brain-stem. These showed (1) at least three areas of heterotopic cortical tissue, containing elements of all three layers, in the white substance of the right cerebellar hemisphere. (2) Enlargement, in all dimensions, of the right hemisphere; both cortex and white matter were increased. (3) In the inner part of the molecular layer, many myelinated fibres running parallel to the surface and at right angles to the folia ; these were accordingly identified as basket-cell fibres. (4) A rich network of fibres in the granular layer; the granule nuclei themselves were of normal size (about $4 \mu$ diameter) but appeared poor in chromatin, and stained more lightly than usual (these last two findings correspond with what was seen on the left side in our second case). (5) Certain anomalies of cell-grouping; for instance, Purkinje cells were seen scattered in the molecular layer, and occasionally in the granule layer. The size of the Purkinje bodies was normal, about 34 to $48 \mu$ in the long axis. (6) Scattered microscopic areas in the left hemisphere showed a similar picture. (7) Abnormalities were found in the cerebellar connexions, both afferent and efferent, including (a) local widening of the dorsal layer of the left inferior olivary nucleus. This appeared to be due to increase in the number of intercurrent fibres. The nuclear cells were normal in size and appearance. There were similar changes observed at a few points in the olive on the right. (b) Increased bulk of the right restiform body was apparently due to increase in number, not size, of the component fibres. (c) Increased width of the right dentate nucleus, analogous to that seen in the opposite olive. (d) Increased bulk of the right brachium conjunctivum, from an increased number of fibres.

The brachium pontis and the pons itself were also thickened. The rest of the brain, including glia, meninges, and blood vessels, showed no abnormality.

The author considers that the basis of the condition is a local arrest of normal development, occurring some time during the sixth month of intra-uterine life. He bases this on the abnormal lamellar pattern and on the irregular placing of the Purkinje cells. The hyperplastic features are associated with this, as they commonly are in other cases of developmental arrest, for instance, microand macrogyria. For the heterotopia, he suggests two alternative explanations, based on previous work ; first, that outward migration of cells from the ventricular cell layer has been cut short, and second, that there has been excessive migration inwards from the embryonic cortical layer, perhaps through the agency of invading blood vessels.

The author quotes evidence that in cases of microgyria the maldeveloped areas correspond to the distribution of individual arteries, and takes the view that anomalies of local vascular development may also have played a part in producing this condition, in spite of the lack of visible vascular $\stackrel{\mathbb{Q}}{\varrho}$ changes. This is interesting, in view of the vascularo changes which have been observed in many of the cases under review.

Concluding, as he does, that this is a hyperplastic condition, primarily affecting the cerebellum, Spiegel draws particular attention to the associated hyperplasia of the efferent systems (dentate nucleus and brachium conjunctivum), and the more surprising "retrograde hyperplasia" of the afferent systems-inferior olive and pons, and their fibretracts.

The principal common findings in the 12 cases under discussion (including Spiegel's case) can be tabulated as follows :

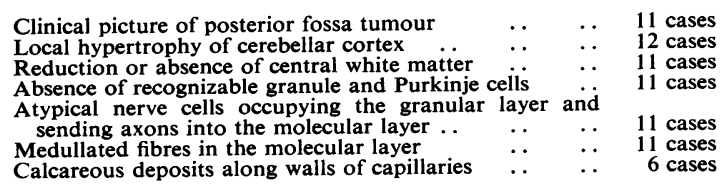

The remaining features are summarized in the Table.

\section{Discussion}

"Such appearances", as Bielschowsky remarked in connexion with Case 3, " are encountered neither in malformations of the cerebellum nor in infiltrating, expanding blastomas". Nevertheless, he concluded that the tumour in question partook 
TABLE

SUMMARY OF CASES DISCUSSED

\begin{tabular}{|c|c|c|c|c|c|c|c|}
\hline Case & Authors & Sex & Age & $\begin{array}{c}\text { Length of } \\
\text { History }\end{array}$ & Site & Special Features & Progress \\
\hline 1 & Lhermitte and Duclos (1920) & M. & 36 & $1 \mathrm{yr}$. & L. $\frac{1}{2}$ sph. & - & $\begin{array}{l}\text { Death from intracranial } \\
\text { pressure without surgical } \\
\text { intervention }\end{array}$ \\
\hline 2 & Schmidt (1926) & $\mathbf{M}$. & 45 & $? 10 \mathrm{yr}$ & L. $\frac{1}{2}$ sph. & $\begin{array}{l}\text { Left-sided skull deformity, } \\
\text { multiple tumours in brain } \\
\text { and elsewhere. Hetero- } \\
\text { topia cerebelli }\end{array}$ & Died of pneumonia \\
\hline 3 & $\begin{array}{l}\text { Bielschowsky and Simons } \\
(1930)\end{array}$ & F. & 20 & $2 \mathrm{yr}$. & $\begin{array}{l}\text { R. } \frac{1}{2} \text { sph. and } \\
\text { tonsil }\end{array}$ & $\begin{array}{l}\text { Polydactyly. in } \begin{array}{c}\text { Hydromyelia. } \\
\text { Atrophy } \\
\text { olive }\end{array} \\
\text { contralateral }\end{array}$ & $\begin{array}{l}\text { Death on table following } \\
\text { bone removal }\end{array}$ \\
\hline 4 & Foerster and Gagel (1933) & F. & 43 & $1 \mathrm{yr}$. & L. $\frac{1}{2}$ sph. & $\begin{array}{l}\text { No cerebellar signs or symp- } \\
\text { toms }\end{array}$ & Death on table \\
\hline 5 & Barten (1934) & F. & 37 & $7 \mathrm{yr}$. & $\begin{array}{l}\text { R. } \frac{1}{2} \text { sph. } \\
\text { (upper half) }\end{array}$ & Thin skull. Hydromyelia & $\begin{array}{l}\text { Death from respiratory } \\
\text { failure }\end{array}$ \\
\hline 6 & Christensen (1937) & M. & 34 & $6 \mathrm{yr}$. & R. $\frac{1}{2}$ sph. & $\begin{array}{l}\text { No cerebellar signs or symp- } \\
\text { toms }\end{array}$ & $\begin{array}{l}\text { Alive and well } 18 \text { months } \\
\text { after local resection }\end{array}$ \\
\hline 7 & $\begin{array}{r}\text { Heinlein and Falkenberg } \\
(1939)\end{array}$ & $\mathbf{M}$. & 23 & 2 yr. & $\begin{array}{l}\text { R. } \frac{1}{2} \text { sph. and } \\
\text { vermis }\end{array}$ & - & $\begin{array}{l}\text { Death from respiratory } \\
\text { failure one day after } \\
\text { posterior fossa decom- } \\
\text { pression }\end{array}$ \\
\hline 8 & $\begin{array}{l}\text { Duncan and Snodgrass } \\
(1943)\end{array}$ & F. & 27 & $1 \frac{1}{2} \mathrm{yr}$ & L. $\frac{1}{2}$ sph. & $\begin{array}{l}\text { Multiple haemangiomata. } \\
\text { Small areas affected in right } \\
\text { hemisphere }\end{array}$ & $\begin{array}{l}\text { Death one day after decom- } \\
\text { pression }\end{array}$ \\
\hline \multirow[t]{2}{*}{9} & $\begin{array}{l}\text { Alajouanine, Bertrand, and } \\
\text { Sabouraud (1951) }\end{array}$ & F. & 26 & ? $8 \mathrm{yr}$. & L. $\frac{1}{2}$ sph. & $\begin{array}{l}\text { Portion of } \mathbf{R} \text {. anterior obe } \\
\text { affected }\end{array}$ & $\begin{array}{l}\text { Died spontaneously from } \\
\text { respiratory failure }\end{array}$ \\
\hline & Spiegel (1920) & M. & 22 & 一 & $\begin{array}{l}\text { R. } \frac{1}{2} \text { sph. } \\
\text { Small areas } \\
\text { on } \mathrm{L} \text {. }\end{array}$ & $\begin{array}{l}\text { No neurological disturbances. } \\
\text { Right leontiasis ossea and } \\
\text { heterotopia cerebelli. Hyper- } \\
\text { plastic picture, with in- } \\
\text { crease in white matter and } \\
\text { changes in olives and } \\
\text { dentate nucleus }\end{array}$ & Died of tuberculosis \\
\hline S.S. & (This paper) & M. & 52 & 2 yr. & $\begin{array}{l}\text { R. } \frac{1}{2} \text { sph., } \\
\text { espec. tonsil }\end{array}$ & $\begin{array}{l}\text { Angiomatous vessels in } \\
\text { affected area }\end{array}$ & $\begin{array}{l}\text { Alive and well one year } \\
\text { after local excision and } \\
\text { ventriculostomy }\end{array}$ \\
\hline J.D. & (This paper) & M. & 21 & 5 months & R. $\frac{1}{2}$ sph. & No cerebellar signs & Operative death \\
\hline
\end{tabular}

of the nature of both, and almost all the subsequent commentators have taken a similar view. The idea of a developmental abnormality seems to have been suggested by the absence of the normal cellular elements of the cerebellum, and the presence, in a more or less regular arrangement, of cells of an abnormal type, while the evidence for neoplasia lies in the recurring clinical picture of an expanding tumour arising in adult life, and the appearance of cells of an "immature", " blastomatous" type, similar to those found in ganglion cell tumours elsewhere in the central nervous system.

The main objection to the "embryological" view is that none of the recognized congenital malformations of the cerebellum seem to afford a likely starting-point for the disease in question. It is, of course, possible that the condition described by Spiegel, and the abnormal myelination observed in the comparatively normal areas in our second case, represent a pre-neoplastic stage of the disease ; but there is no evidence that these abnormalities are of embryological origin. This uncertainty about the nature of the postulated hamartoma is illustrated by the fact that whereas Bielschowsky and Simons (1930) suggest that the condition is due to local agenesis of the transitory superficial cortex, Kuhlenbeck (1950), in discussing this among other cerebellar tumours, regards them all as neoplasms arising from abnormally persisting remnants of the same layer.

Another objection is the absence, in the cases under review, of cerebellar disturbances in early life. This, however, can be countered with the well-known phenomenon of functional compensation for loss of cerebellar tissue.

The objections to the "neoplastic" view are more serious; namcly, the remarkably orderly behaviour of the cells, which spread out in two dimensions only, and emit processes which all pursue a similar course in the molecular layer. 
They do not even give the impression of infiltration in the molecular layer. The absence of mitotic figures is a further argument against neoplasia.

There remains the "hypertrophic" theory of Duncan and Snodgrass (1943). This is simply based on the arrangement of the fibres in the molecular layer, which corresponds precisely to that of normal granule axons. (Further confirmation of this was obtained in the two cases reported in this paper, which showed the horizontally disposed fibres running along, rather than across the length of the folia.) The argument is very persuasive, as it is almost impossible to conceive of truly neoplastic cells being under such strict neurobiotactic control as to mimic exactly with their axons the fibre-pattern of the cells they are replacing. The theory is attractive, too, because it enables one to offer a tentative explanation of most of the changes observed in the diseased tissue. Thus, granule cells are absent, not because of agenesis or destruction, but because they have undergone a hypertrophic change. A normal granule cell has a diameter of $4 \mu$; in the two cases described here, the abnormal cells have an average diameter of 12 to $16 \mu$. If they are in fact granule cells, this implies an increase in volume of 27 to 64 times, and there is no need to postulate an increase in cell numbers to account for the greatly increased thickness of this layer ; in fact, one must suppose that there has been a large-scale disappearance of cells. The increased thickness of the molecular layer can similarly be attributed to the increase in calibre and partial myelination of the component fibres, without increase in their numbers.

There are one or two objections to the " hypertrophic" theory. One is that the cells in question look wholly unlike granule cells. This would be weightier if we possessed the knowledge enabling us to predict what a hypertrophied granule cell ought to look like. In any case, the difference is not much more striking than the difference between normal microglia and compound granular corpuscles. A more serious objection is that many learned authors have described the cells, in no uncertain terms, as neuroblasts of various degrees of maturity. It is only fair to point out that in so doing they are not merely describing the cells; they are also interpreting them, and drawing implicit conclusions about their origins and destinies, which it would be very hard to substantiate. Bielschowsky himself was clearly unhappy about the idea of a neuroblast with a well developed, myelinated axon. Again, the fact that these cells are closely similar to those found in ganglioneuromas elsewhere in the brain may point in one of two directions.
It would be worth while re-examining some cases of this condition, to see whether a hypertrophic theory might not fit them as closely as a neoplastic one.

A feature for which none of the previous authors has offered an explanation is the reduction or disappearance of the central white matter. It might be supposed that this was an effect of the increased pressure in the posterior fossa, analogous to the preferential loss of cerebral white matter in hydrocephaly. Against this is the fact that in the molecular layer "white matter" has actually appeared and increased in width. Another possibility is that the centrifugal and centripetal fibres which compose the white matter are adversely affected by the changes occurring in the granular layer, through which they all pass, and undergo Wallerian and retrograde degeneration in consequence. The same mechanism might account for the disappearance of Purkinje cells, which can be thought of as decomposing as a result of destruction of their axons. These cells seem to be particularly sensitive to adverse conditions, and are the first to disappear, for instance, in ischaemic lesions of the cerebellum.

The finding, in several of the reported cases, of degenerating Purkinje cells and empty basketformations in the "transitional" areas strongly suggests that the disappearance of these cells is secondary to the other changes taking place, rather than that they are congenitally lacking. The appearances in the transitional area in our second case also argue against Christensen's (1937) view that the tumour is a "Purkinjeoma". Here one sees a continuous gradation of cell types in the granular layer, from normal granule cells to the abnormal types, but nothing resembling a Purkinje cell, with its characteristic dendrite formation, can be seen. The fact that many of the larger abnormal cell bodies have similar staining properties to those of Purkinje cells is probably without significance. The appearance of a cell body and its nucleus presumably reflects the cell's metabolic behaviour, whereas the manner in which it disposes its long processes would seem to be a far more fundamental characteristic of a particular species of nerve cell.

Since the disease has the clinical features of a progressively enlarging tumour, it is reasonable to suppose that it proceeds by horizontal spread from one or more centres in the cortex. If this is so, the "transitional" areas represent the lines along which normal is being transformed into abnormal cortex and one can reasonably regard the changes observed in following the cortex from a normal to an abnormal part as indications of the 
changes which occur in time as a given bit of tissue is overtaken by the disease. On this assumption, the earliest visible change is the myelination of basket and granule cell fibres; next, increase in size and changes in staining properties of granule cells ; next, degeneration of Purkinje cells, which finally disappear, leaving empty basket-formations behind them; next, gross hypertrophy of the granule cells and their processes; and lastly, the thinning-out and disappearance of the central white matter.

Whether Spiegel's case showed an early stage of the same disease is difficult to decide. The reasons he gives for regarding the condition as a hyperplasia are not wholly convincing; some of his observations tally with the "early" changes in our second case ; and the conjunction of leontiasis ossea, heterotopia cerebelli, and cerbellar hypertrophy, which was also present in Case 2 of the reported series, is very striking.

If the hypertrophic theory is correct, we still have the difficulty of finding a reason for the hypertrophy. At present, there is no clue to an underlying cause, with the possible exception of the changes which have in most cases been observed in the small blood vessels of the region. These seem to have been most marked in our first case, which showed small angiomatous masses at several points. Calcification in capillary walls is found in other conditions, and it is quite possible that the vascular changes are in fact secondary to the changes in the tissue they supply. The fact that several of the patients have shown congenital abnormalities in other parts of the body has been taken by some authors as evidence that the disease is genetically determined ; but there is no constant feature in the observed aberrations of development, and in over half the patients no such abnormalities were discovered. A genetic cause is, however, a possibility, and should be considered along with the other possibilities, such as neoplasia or even a virus infection.

On the question of diagnosis and treatment there is not very much to say. There appears to be no clinical feature by which the condition can be distinguished from other posterior fossa tumours; on the other hand, it should be readily recognizable in the course of a cerebellar exploration, from the appearance of pale, expanded folia, and the absence of a definite neoplastic mass. It is worth noting that whereas the rapid examination of frozen sections from a biopsy specimen would probably provide a clear answer, a smear biopsy would not. The correct treatment would seem to be an excision of the diseased part, if (as is the case with the tonsil) it is surgically accessible, and relief of the obstructive hydrocephalus by some short-circuiting procedure such as anterior ventriculostomy.

As to nomenclature, the term "diffuse hypertrophy of the cerebellar cortex", suggested by Duncan and Snodgrass, seems to fit the case without begging any questions.

\section{Summary}

Reports are given of two cases of diffuse hypertrophy of the cerebellar cortex, with clinical histories and pathological findings.

A review is given of nine previously reported cases of the same condition, and of a tenth, which is believed to display an earlier stage of the condition.

The nature of the disease is discussed, and reasons given for believing that it is of a hypertrophic rather than of a neoplastic type.

Some remarks are made on diagnosis and treatment.

I wish to express my thanks to Dr. W. H. McMenemey, pathologist at the Maida Vale Hospital, for his continuous interest and help in preparing this paper; to Mr. W. R. Henderson, of Leeds, for his kindness in making available the material for the second case ; to Sir Russell Brain, under whose care the first case originally came, and to Mr. Valentine Logue, the surgeon in charge of the case, for their help and encouragement ; and to Mr. Gordon Cox and Mr. Frank Blackwell for their valuable technical assistance.

\section{REFERENCES}

Alajouanine, T., Bertrand, I., and Sabouraud, C. (1951). Rev. neurol., Paris, 84, 3.

Barten, H. (1934). Beitr. path. Anat., 93, 219.

Bielschowsky, M., and Simons, A. (1930). J. Psychol. Neurol., Lpz., 41, 50 .

Christensen, Erna (1937). Virchows Arch. path. Anat., 300, 567.

Duncan, D., and Snodgrass, S. R. (1943). Arch. Neurol. Psychiat., Chicago, 50, 677 .

Foerster, O., and Gagel, O. (1933). Z. ges. Neurol. Psychiat.,' 146, 792.

Heinlein, H., and Falkenberg (1939). Ibid., 166, 128.

Kuhlenbeck, H. (1950). J. Amer. med. Wom. Ass., 5, 347.

Lhermitte and Duclos (1920). Bull. Ass. franc. Cancer, 9, 99.

Schmidt, M. B. (1926). Beitr. Anat. etc, Ohr., 23, 594.

Spiegel, E. (1920). Beitr. path. Anat., 67, 539. 